\title{
The Stimulatory Effect of Platelets and Platelet Membranes on the Procoagulant Activity of Leukocytes
}

\author{
Julian Niemetz and Aaron J. Marcus \\ From the Hematology Section, Bronx Veterans Administration Hospital, Bronx, \\ New York 10468; the Department of Medicine, Mount Sinai School of Medicine, \\ New York 10029; the Hematology Section, New York Veterans Administration \\ Hospital, New York 10010; and the Department of Medicine, New York \\ Hospital-Cornell Medical Center, New York 10021
}

A B S T RAC T Leukocytes can generate procoagulant (tissue factor) activity when incubated with endotoxin. These studies were undertaken to determine whether platelets could influence the procoagulant activity generated by leukocytes. Intact or disrupted platelets (rabbit or human) enhanced the clot-promoting properties of rabbit leukocytes.

The enhancing effect of human platelets on human leukocytes required the presence of human serum (devoid of factor VII and $\mathrm{X}$ activities). When platelets were incubated with endotoxin in the absence of leukocytes, no increase in their clot-promoting properties was discernible. However, a mixture of platelets, leukocytes, and endotoxin generated procoagulant activity which appeared rapidly and was fivefold greater than that produced by leukocytes incubated with endotoxin alone. The enhancement produced by platelets was even more pronounced if homogenates were used. The platelet effect was examined in more detail by the substitution of membranes, granules, and the "soluble" fraction for whole platelets in the test system. The stimulating activity was localized to the particulate fractions, i.e. membranes and granules. Prior treatment of platelet membranes with phospholipase $\mathrm{C}$ or gangliosides or by extraction of lipid resulted in loss of enhancing activity, whereas no inhibition was observed after exposure to neuraminidase or trypsin. It is proposed that platelets contribute a membrane lipoprotein surface which enhances the procoagulant activity generated by leukocytes in the presence of endotoxin. This mechanism may be involved in some of the clinical and pathologic manifestations of gram-negative sepsis with disseminated intravascular coagulation.

\footnotetext{
Received for publication 4 June 1974 and in revised form 5 August 1974.
}

\section{INTRODUCTION}

It is well established that procoagulant activity can be demonstrated in leukocytes $(1-4)$ and that this activity is related to the extrinsic (tissue factor) pathway of blood coagulation (4-8). In addition, it has been shown that the procoagulant activity present in leukocytes can be greatly enhanced by endotoxin. The enhancement can be demonstrated in two ways: $(a)$ it is measureable in peritoneal leukocytes from a rabbit treated with endotoxin (6); and (b) it can be detected in vitro in human leukocyte suspensions which have been exposed to endotoxin (7-9). Of further interest is the observation that tissue factor activity thus generated possesses a marked thrombogenic effect (10). These observations have recently been confirmed and extended to rabbit (11) and canine (12) leukocytes as well as lymphocytes $(9,13)$ and macrophages $(9)$.

In 1968 Biggs, Denson, Riesenberg, and McIntyre reported that tissue factor activity was demonstrable in platelets that were incubated in plasma for $16-20 \mathrm{~h}$ at $37^{\circ} \mathrm{C}$. The development of this activity required the presence of factor XII but no other coagulation factors (14). It is known that in gram-negative sepsis or after injection of endotoxin the number of circulating platelets decreases $(15,16)$. Furthermore, it has been reported that platelet-rich plasma administered intracutaneously to rabbits produces a leukotactic effect and "prepares" the site for the local Shwartzman reaction (17). Therefore it was of interest to determine whether platelets might influence the procoagulant activity generated by leukocytes. In this report it will be shown that rabbit or human platelets, as well as subcellular particles derived from human platelets, are capable of augmenting the quantity and rate of tissue factor activity present in leukocytes. 


\section{METHODS}

Rabbit leukocyte preparations were obtained from arterial blood anticoagulated with 0.1 vol $4 \%$ trisodium citrate dihydrate. The whole blood was sedimented with Dextran $250,{ }^{1}$ and the leukocyte suspension was washed six times in citrated saline (5 parts $0.15 \mathrm{M}$ saline: 1 part $4 \%$ trisodium citrate dihydrate at $4^{\circ} \mathrm{C}$, as previously described [9]). The leukocytes were then suspended at the desired concentration in a balanced salt solution (Hanks'), which contained $100 \mathrm{U}$ each of penicillin and streptomycin per $\mathrm{ml}$. The final concentration of leukocytes in the incubation mixture was 2,000 per $\mathrm{mm}^{3}$. Human leukocytes were obtained from venous blood and processed in a similar manner. Final concentration of human leukocytes in the incubation mixtures was 10,000 per $\mathrm{mm}^{3}$. Leukocytes were counted in a Coulter Counter. ${ }^{3}$

Rabbit platelets were prepared as follows: Whole blood was collected in silicone-coated tubes ${ }^{*}$ with disodium ethylenediaminetetraacetate $(\text { EDTA })^{5}(2 \%)$ in $0.15 \mathrm{M}$ saline as anticoagulant. The blood was centrifuged at $160 \mathrm{~g}$ for 5 $\min$ at $28-30^{\circ} \mathrm{C}$. This step was repeated when necessary. The platelet-rich plasma was then centrifuged at $40 \mathrm{~g}$ for $10 \mathrm{~min}$ in order to render it leukocyte free. The platelets were sedimented at $1,100 \mathrm{~g}$ for $15 \mathrm{~min}$ and subsequently washed in the solutions described by Ardlie $(18,19)$. Thus, the first wash was a modified Tyrode's solution ( $\mathrm{pH} 6.5$ ) containing ethylene glycol-bis- ( $\beta$-aminoethyl ether) $N, N^{\prime}$-tetraacetic acid (EGTA), magnesium, bovine albumin, ${ }^{\circ}$ apyrase $^{7}(100 \mu \mathrm{g}$ per $\mathrm{ml}$ ), but no calcium. The second wash was a modified Tyrode's solution prepared as above but omitting EGTA. The platelets were finally suspended in a Tyrode's solution containing $0.35 \%$ bovine albumin and $100 \mu \mathrm{g}$ apyrase per $\mathrm{ml}$. To this was added $100 \mathrm{U}$ each of penicillin and streptomycin per $\mathrm{ml}$. The final concentration of platelets in an incubation mixture was 160,000 per $\mathrm{mm}^{3}$. Platelets were counted by phase-contrast microscopy, and the absence of leukocytes was validated by examination of stained smears. For some experiments the platelets were disrupted by sonification for $15 \mathrm{~s}$ with a microprobe set at position $5^{8}$ In specific experiments the sonified platelets were heated at $100^{\circ} \mathrm{C}$ for $10 \mathrm{~min}$. Human platelets were processed in the same manner, except that the anticoagulant used was acid citrate dextrose (ACD).

Subcellular fractions were prepared from human platelets as previously described (20). In several instances the initial homogenate was prepared with a blade-type homogenizer ${ }^{\circ}$ at $45,000 \mathrm{rpm}$ for $5 \mathrm{~min}$ at $4^{\circ} \mathrm{C}$ with one repetition after a 5-min cooling period. The source of platelets was 12-48-h-old concentrates obtained from the New York

${ }^{1}$ Pharmacia Fine Chemicals, Inc., Piscataway, N. J.

2 Difco Laboratories, Detroit, Mich.

'Coulter Electronics, Inc., Fine Particle Group, Hialeah, Fla.

'Siliclad, Clay Adams, Div. of Becton, Dickinson \& Co., Parsippany, N. J.

SAbbreviations used in this paper: ACD, acid citrate dextrose; EDTA, disodium ethylenediaminetetraacetate; EGTA, ethylene glycol-bis-( $\beta$-aminoethyl ether) $N, N^{\prime}$-tetraacetic acid.

- Bovine albumin, $3 \times$ crystallized, Armour Pharmaceutical Company, Chicago, Ill.

'Sigma Chemical Co., St. Louis, Mo.

- Sonifier model W 140, Heat Systems-Ultrasonics, Inc., Plainview, N. Y.

'Model 16 600, VirTis Co., Inc., Gardiner, N. Y.
Blood Center. Approximately $40 \mathrm{U}$ of platelet concentrates were processed on each occasion, as previously noted (21), except that sterile, pyrogen-free, $0.15 \mathrm{M}$ saline was used throughout the washing procedure. Adsorbed serum was prepared as previously reported (8).

Endotoxins ${ }^{2}$ Lipopolysaccharide B from Salmonella marcescens (Boivin and Westphal), Escherichia coli 055B5 (Westphal and Boivin), Salmonella typhimurium (Boivin), and $E$. coli 026B6 (Boivin) were used as fresh suspensions. Unless otherwise indicated $E$. coli $026 \mathrm{~B} 6$ endotoxin was used throughout, at a final concentration of $10 \mu \mathrm{g}$ per $\mathrm{ml}$.

The dextran preparations, tricalcium phosphate, and all glassware employed were sterilized and rendered endotoxin free by heating for $3 \mathrm{~h}$ at $160^{\circ} \mathrm{C}$.

All other reagents were suspended in pyrogen-free distilled water or $0.15 \mathrm{M}$ pyrogen-free saline and filtered through Millipore ${ }^{10}$ filters with a pore diameter of $0.22 \mu \mathrm{m}$. The filtration procedure did not remove endotoxin. Blood collections and processing were carried out in pyrogen-free plastic $^{11}$ or siliconized containers. Meticulous care was taken to preserve sterility. Leukocytes and platelets were incubated at $37^{\circ} \mathrm{C}$ in tightly stoppered, sterile plastic- or silicone-coated tubes. Phospholipase $\mathrm{C}^{12}$ neuraminidase, ${ }^{13}$ trypsin, ${ }^{7}$ soy bean trypsin inhibitor, ${ }^{7}$ ganglioside type III, ${ }^{7}$ and apyrase were all purchased. Protein determinations were carried out with the Folin Ciocalteu reagents (22). Tyrosine was used as the standard, and a multiplication factor of 20 was used to express results as milligram of protein per milliliter.

The coagulant activity generated in the incubation mixtures was evaluated at predetermined intervals by a onestage test. Components of the system were as follows: 0.1 $\mathrm{ml}$ incubating mixture, $0.1 \mathrm{ml} \mathrm{CaCl}(0.025 \mathrm{M})$, and $0.1 \mathrm{ml}$ of plasma derived from the same species as the leukocyte donor. Constituents were added in the above order, and the clotting time was recorded. The incubation mixtures were also assayed for tissue factor activity by using the twostage system described by Nemerson (23) with minor modifications (6). The standard preparation of thromboplastin (6) was arbitrarily assigned a value of $1,000 \mathrm{U}$ per $\mathrm{ml}$. A representative correlation between clotting times and tissue factor units is as follows: $100 \mathrm{U}-13.5 \mathrm{~s}, 50 \mathrm{U}-16.8$ $\mathrm{s}, 25 \mathrm{U}-21.2 \mathrm{~s}, 10 \mathrm{U}-28.8 \mathrm{~s}$. Results vary with different batches of reagents.

\section{RESULTS}

Rabbit leukocytes and rabbit platelets. The one-stage test and two-stage assay for procoagulant activity were carried out on leukocytes after incubation alone and with platelets. In the presence of platelets the clot-promoting properties of leukocytes were markedly enhanced. The clotting activity was further increased after incubation of the leukocytes with disrupted platelets (Table I). The platelet-enhancing effect was maximal if assays were carried out on platelets prepared immediately after blood collection.

In another series of experiments endotoxin preparations were added to incubation mixtures of leukocytes

\footnotetext{
${ }^{10}$ Millipore Corp., Bedford, Mass.

"Falcon Plastics, Division of B-D Laboratories, Inc., Oxnard, Calif.

Worthington Biochemical Corp., Freehold, N. J.

${ }^{1 s}$ Behring Diagnostics, Inc., Sommerville, N. J.
} 
and platelets. This resulted in a consistent shortening of the clotting time as well as an increase in the tissue factor activity generated by the leukocytes. The stimulative effect of platelets was decreased significantly if the homogenate was heated $\left(100^{\circ} \mathrm{C}, 10 \mathrm{~min}\right)$ before inclusion in the incubation mixture. On the other hand, if endotoxin was added to the heated platelet homogenates, there was considerable enhancement of tissue factor activity (an increase from 8 to $81 \mathrm{U}$ ). This suggested the presence of two separate factors in the platelet homogenates, one thermolabile and unrelated to the endotoxin effect and the second thermostable and sensitive to the presence of endotoxin in the incubation system (Table I).

The incubation mixtures were subsequently tested at hourly intervals in order to determine the effect of platelets and endotoxin upon the rate at which the procoagulant activity of leukocytes was generated. In Fig. 1 it can be seen that platelet preparations incubated with endotoxin in the absence of leukocytes showed insignificant procoagulant activity. On the other hand, when the platelets were incubated with leukocytes a significant increase in procoagulant activity could be measured.

TABLE I

Effect of Rabbit Platelets on the Procoagulant Activity of Rabbit Leukocytes

\begin{tabular}{|c|c|c|c|}
\hline & \multicolumn{2}{|c|}{$\begin{array}{c}\text { One-stage } \\
\text { test } \\
\text { (clotting } \\
\text { times) }\end{array}$} & \multirow{2}{*}{$\begin{array}{c}\text { Tissue } \\
\text { factor } \\
\text { activity } \\
\text { at } 18 \mathrm{~h}\end{array}$} \\
\hline & $\mathrm{Oh}$ & $18 \mathrm{~h}$ & \\
\hline & \multicolumn{2}{|c|}{$s$} & $U$ \\
\hline WBC + platelets & 153 & 74 & 7 \\
\hline WBC + disrupted platelets & 144 & 33 & 65 \\
\hline WBC + Tyrode-albumin-apyrase & 165 & 105 & 2 \\
\hline $\mathrm{WBC}+$ platelets + endotoxin & 147 & 34 & 61 \\
\hline $\begin{array}{l}\text { WBC + disrupted platelets } \\
\text { +endotoxin }\end{array}$ & 146 & 26 & 128 \\
\hline $\begin{array}{l}\text { WBC + Tryode-albumin-apyrase } \\
+ \text { endotoxin }\end{array}$ & 167 & 40 & 51 \\
\hline $\begin{array}{l}\text { WBC + disrupted platelets, } \\
100^{\circ} \mathrm{C}\end{array}$ & 154 & 62 & 8 \\
\hline $\begin{array}{l}\text { WBC + disrupted platelets, } \\
100^{\circ} \mathrm{C},+ \text { endotoxin }\end{array}$ & 159 & 27 & 81 \\
\hline WBC + endotoxin & 174 & 47 & 24 \\
\hline $\mathrm{WBC}+$ saline & 189 & 152 & 1 \\
\hline
\end{tabular}

Incubation system: $0.1 \mathrm{ml}$ of rabbit leukocytes in Hanks' solution (final concentration 2,000 per $\mathrm{mm}^{3}$ ); $0.1 \mathrm{ml}$ of saline or endotoxin $(5 \mu \mathrm{g})$ in saline; $0.1 \mathrm{ml}$ of platelets (rabbit) in Tyrode-albumin-apyrase solution (final concentration 160,000 per $\mathrm{mm}^{3}$ ). These reactants were added to $0.2 \mathrm{ml}$ Tyrode's solution, mixed, incubated at $37^{\circ} \mathrm{C}$, and tested as shown above.

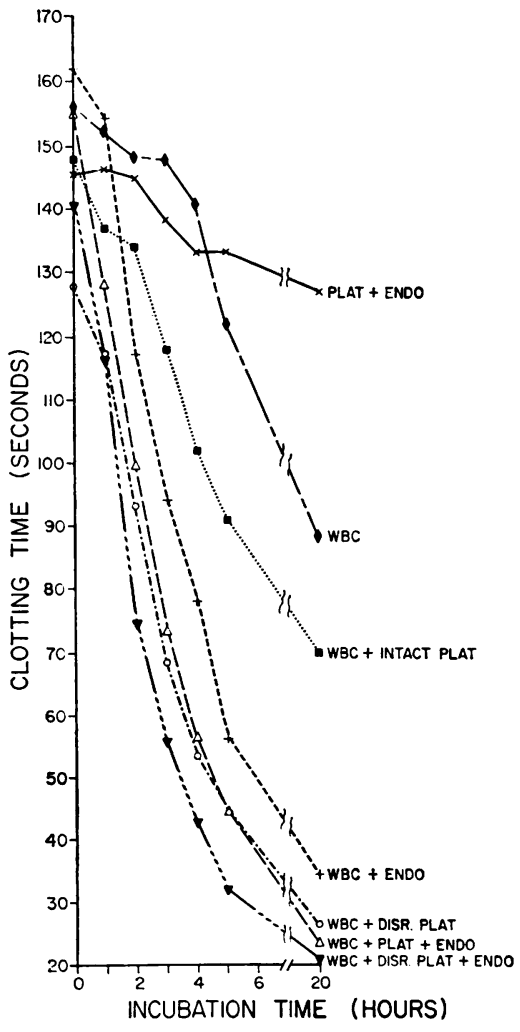

FIGURE 1 Effect of rabbit platelets on the procoagulant activity of rabbit leukocytes. The procoagulant activity (one-stage test) was determined at the indicated time intervals. Incubation system: components were used in the same proportions as in Table I. disr., disrupted; endo, endotoxin; plat, platelets; WBC, leukocytes.

After incubation of leukocytes with disrupted platelets and endotoxin, the rate and quantity of procoagulant activity generated were maximal.

Rabbit leukocytes and human platelets. If human platelets were substituted for rabbit platelets in the incubation mixture with rabbit leukocytes, comparable results were obtained: that is, the clot-promoting properties of rabbit leukocytes were enhanced.

Rabbit leukocytes and subcellular fractions derived from human platelets. An attempt was then made to discern whether the procoagulant activity generated by leukocytes in the presence of platelets could be attributed to a particular subcellular platelet component. Thus freshly prepared ${ }^{14}$ platelet membranes, granules, and the soluble fraction, respectively, were incubated with leukocytes in the presence of endotoxin. After an appropriate incubation period, all three subcellular platelet fractions enhanced the procoagulant acitvity of the leukocytes as assayed by the one-stage coagulation time ( $\mathrm{Ta}$ -

${ }^{14}$ Isolated from platelet concentrates which were $12-48 \mathrm{~h}$ old. 
TABLE II

Procoagulant Activity (One-Stage Test) of Leukocytes after Incubation with Platelet Subcellular Fractions in the Presence of Endotoxin

\begin{tabular}{|c|c|c|c|c|c|c|}
\hline \multirow{2}{*}{$\begin{array}{l}\text { Protein } \\
\text { content }\end{array}$} & \multicolumn{2}{|c|}{$\begin{array}{c}\text { Platelet } \\
\text { membranes }\end{array}$} & \multicolumn{2}{|c|}{$\begin{array}{l}\text { Platelet } \\
\text { granules }\end{array}$} & \multicolumn{2}{|c|}{$\begin{array}{l}\text { Soluble } \\
\text { fraction }\end{array}$} \\
\hline & $0 \mathrm{~h}$ & $18 \mathrm{~h}$ & $\mathrm{Oh}$ & $18 \mathrm{~h}$ & $\mathrm{Oh}$ & $18 \mathrm{~h}$ \\
\hline$m g / m l$ & \multicolumn{2}{|c|}{$s$} & \multicolumn{2}{|l|}{$s$} & \multicolumn{2}{|l|}{$s$} \\
\hline 0 & 130 & 39 & & & & \\
\hline 0.075 & 109 & 26 & 132 & 31 & 118 & 33 \\
\hline 0.15 & 104 & 27 & 115 & 28 & 112 & 29 \\
\hline 0.3 & 105 & 23 & 110 & 23 & 108 & 27 \\
\hline 0.6 & 103 & 22 & 102 & 21 & 107 & 24 \\
\hline 1.2 & 99 & 22 & 97 & 20 & 108 & 22 \\
\hline 2.4 & 93 & 24 & 92 & 20 & 115 & 22 \\
\hline
\end{tabular}

Incubation mixtures as shown in Table I, except that whole platelets were replaced by subcellular fractions of human platelets and suspended in saline at the above protein concentrations.

ble II). In contrast, when the tissue factor activity of the leukocyte preparation was tested (by the two-stage assay), only the platelet membranes and granules were active. The soluble fraction was inert, indicating that the platelet contribution to the tissue factor activity of leukocytes was particulate in nature. Control studies in which the subcellular platelet fractions were incubated

TABLE III

Tissue Factor Activity Generated by Leukocytes after 18-h Incubation with Platelet Subcellular Fractions and Endotoxin

\begin{tabular}{lccc}
\hline $\begin{array}{l}\text { Protein } \\
\text { content }\end{array}$ & $\begin{array}{c}\text { Platelet } \\
\text { membranes } \\
(-\Delta \text { endotoxin })\end{array}$ & $\begin{array}{c}\text { Platelet } \\
\text { granules } \\
(-\Delta \text { endotoxin })\end{array}$ & $\begin{array}{c}\text { Platelet } \\
\text { soluble } \\
\text { proteins } \\
(-\Delta \text { endotoxin })\end{array}$ \\
\hline$m g / m l$ & $U$ & $U$ & $U$ \\
0.075 & 21 & 15 & - \\
0.15 & 27 & 12 & 5 \\
0.3 & 61 & 42 & 13 \\
0.6 & 89 & 98 & 20 \\
1.2 & 173 & 145 & 27 \\
2.4 & 215 & 198 & 32 \\
Controls (U) & & & \\
WBC + endotoxin : 35 & & \\
WBC + saline: 2 & & \\
Platelet granules + endotoxin: 0 & \\
Platelet soluble protein + endotoxin : 0 \\
Platelet membranes + endotoxin: 0
\end{tabular}

Incubation mixtures as shown in Table II. The tissue factor activity of leukocytes and endotoxin alone (35 U) was subtracted in each instance from that obtained in the presence of platelet fractions, endotoxin, and leukocytes $(-\Delta$ endotoxin).
TABLE IV

Effect of Platelets and Adsorbed Serum on the Procoagulant Activity of Human Leukocytes

\begin{tabular}{|c|c|c|c|c|c|c|}
\hline & \multicolumn{3}{|c|}{$\begin{array}{l}\text { Without adsorbed } \\
\text { serum }\end{array}$} & \multicolumn{3}{|c|}{$\begin{array}{l}\text { With adsorbed } \\
\text { serum* }\end{array}$} \\
\hline & \multicolumn{2}{|c|}{$\begin{array}{c}\text { One-stage } \\
\text { test } \\
\text { (clotting } \\
\text { times) }\end{array}$} & \multirow{2}{*}{$\begin{array}{r}\text { Tissue } \\
\text { factor } \\
\text { activity } \\
\text { at } 18 \mathrm{~h}\end{array}$} & \multicolumn{2}{|c|}{$\begin{array}{c}\text { One-stage } \\
\text { test } \\
\text { (clotting } \\
\text { times) }\end{array}$} & \multirow{2}{*}{$\begin{array}{l}\text { Tissue } \\
\text { factor } \\
\text { activity } \\
\text { at } 18 \mathrm{~h}\end{array}$} \\
\hline & $0 \mathrm{~h}$ & $18 \mathrm{~h}$ & & $0 \mathrm{~h}$ & $18 \mathrm{~h}$ & \\
\hline & \multicolumn{2}{|c|}{$s$} & $U$ & \multicolumn{2}{|c|}{$s$} & $U$ \\
\hline WBC + platelets & 128 & 60 & 6 & 127 & 55 & 16 \\
\hline $\begin{array}{l}\text { WBC + platelets } \\
\text { + endotoxin }\end{array}$ & 122 & 47 & 19 & 126 & 35 & 55 \\
\hline $\begin{array}{l}\text { WBC + disrupted } \\
\text { platelets }\end{array}$ & 116 & 84 & 1 & 89 & 53 & 12 \\
\hline $\begin{array}{l}\mathrm{WBC}+\text { disrupted } \\
\text { platelets + endotoxin }\end{array}$ & 119 & 44 & 19 & 90 & 33 & 47 \\
\hline $\begin{array}{l}\text { WBC }+ \text { Tyrode-albumin- } \\
\text { apyrase }\end{array}$ & 168 & 81 & 5 & - & - & - \\
\hline $\begin{array}{l}\text { WBC }+ \text { Tyrode-albumin- } \\
\text { apyrase + endotoxin }\end{array}$ & 167 & 62 & 17 & 159 & 47 & 28 \\
\hline WBC + saline & 168 & 140 & 1 & - & - & - \\
\hline WBC + Tyrode & 162 & 123 & 1 & - & - & - \\
\hline $\begin{array}{l}\text { WBC + Tyrode } \\
\text { + endotoxin }\end{array}$ & 160 & 65 & 11 & - & - & - \\
\hline WBC + endotoxin & 168 & 68 & 10 & 141 & 52 & 22 \\
\hline Platelets + endotoxin & - & - & - & 136 & 84 & 1 \\
\hline
\end{tabular}

Human leukocytes were tested at a final concentration of 10,000 per $\mathrm{mm}^{3}$. Human platelets were studied at a final concentration of 160,000 per $\mathrm{mm}^{3}$. Other reagents as in Table $\mathrm{I}$.

* Human adsorbed serum free of factor VII and X activities. $0.2 \mathrm{ml}$ was used in lieu of Tyrode's solution.

with endotoxin in the absence of leukocytes resulted in no procoagulant activity, indicating that the activity measured was indeed generated by the leukocytes alone. The results are shown in Table III.

Effect of human platelets on the procoagulant activity of human leukocytes. When human platelets and leukocytes were incubated in the standard medium, there was no appreciable effect on the clot-promoting properties of the leukocytes (Table IV). However, if adsorbed human serum was added to the incubation mixture there was marked enhancement of the clotting activity of the leukocytes (Table IV). It was previously ascertained that the adsorbed human serum added to the incubation mixture was devoid of factor VII or X activity. These results were in distinct contrast to the system in which human platelets were added to rabbit leukocytes, wherein there was no requirement for adsorbed human serum.

Effect of biochemical alterations of human platelet membranes. Platelet membranes, after incubation with various agents, were washed and added to the leukocyte suspensions, which were then tested for procoagulant activity $(0 \mathrm{~h})$. After an additional incubation period the activity generated by the leukocytes was again measured. 
Trypsin-treated platelet membranes stimulated the production of tissue factor activity by leukocytes even in the absence of endotoxin. It was of interest that the trypsin-digested membranes shortened the one-stage clotting time without incubation with leukocytes, but no tissue factor activity was generated under these circumstances. However, in the tissue factor assay, trypsintreated platelet membranes in the presence of endotoxin were no more effective than control membranes (no endotoxin) similarly treated with trypsin. It thus appeared that after trypsinization platelet membranes no longer required the presence of endotoxin to enhance the tissue factor activity of leukocytes. The results are shown in Table V.

After treatment of platelet membranes with phospholipase $\mathrm{C}$ the production of leukocyte tissue factor activity was completely inhibited. Conversely, neuraminidase treatment of platelet membranes had no appreciable effect on their enhancement of leukocyte procoagulant activity (Table V).

\section{TABLE V}

Effects of Biochemical Alterations of Platelet Membranes on Their Enhancement of Leukocyte Procoagulant Activity

\begin{tabular}{|c|c|c|c|}
\hline \multirow{2}{*}{$\begin{array}{l}\text { Platelet membranes } \\
\text { treated with: }\end{array}$} & \multicolumn{2}{|c|}{$\begin{array}{l}\text { One-stage test } \\
\text { (clotting times) }\end{array}$} & \multirow{2}{*}{$\begin{array}{l}\text { Tissue } \\
\text { factor } \\
\text { activity } \\
\text { at } 18 \mathrm{~h}\end{array}$} \\
\hline & $0 \mathrm{~h}$ & $18 \mathrm{~h}$ & \\
\hline & \multicolumn{2}{|c|}{$s$} & $U$ \\
\hline $\begin{array}{l}\text { Saline } \\
\text { Saline + endotoxin }\end{array}$ & $\begin{array}{l}91 \\
89\end{array}$ & $\begin{array}{l}45 \\
20\end{array}$ & $\begin{array}{r}13 \\
222\end{array}$ \\
\hline Trypsin & 45 & 23 & 59 \\
\hline Trypsin + endotoxin & 48 & 18 & 202 \\
\hline Trypsin (no leukocytes) & 43 & 62 & 0 \\
\hline Phospholipase C & 106 & 130 & 0 \\
\hline Phospholipase $\mathrm{C}+$ endotoxin & 111 & 131 & 0 \\
\hline Neuraminidase & 80 & 50 & 11 \\
\hline Neuraminidase + endotoxin & 81 & 19 & 212 \\
\hline Ganglioside & 89 & 57 & 9 \\
\hline Ganglioside + endotoxin & 85 & 38 & 14 \\
\hline $\begin{array}{l}\text { Chloroform:methanol } \\
\text { extraction }+ \text { endotoxin }\end{array}$ & 116 & 26 & 38 \\
\hline
\end{tabular}

Platelet membranes (24 mg) were suspended in Hanks' solution and incubated at $37^{\circ} \mathrm{C}$ for $40 \mathrm{~min}$ with the following agents: trypsin (10 $\mathrm{mg}$ per $\mathrm{ml})$; neuraminidase (1 U); phospholipase $C(1 \mathrm{mg})$; ganglioside $(5 \mathrm{mg})$. The mixtures were agitated every $5 \mathrm{~min}$. At the end of the incubation period the mixtures were placed at $0^{\circ} \mathrm{C}$. However, the trypsin-treated membranes were shaken with soy bean trypsin inhibitor $(20 \mathrm{mg}$ ) before cooling. Each mixture was washed twice by centrifugation $(226,000 \mathrm{~g}$ for $70 \mathrm{~min})$ in sterile pyrogen-free saline. The treated membranes (final concentration, $2.4 \mathrm{mg} / \mathrm{ml}$ ) were then incubated with rabbit leukocytes in the presence or absence of endotoxin.

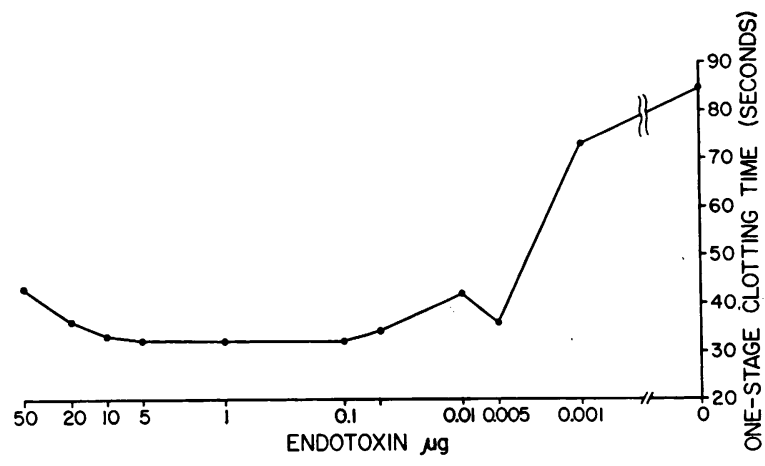

FIGURE 2 Effect of various quantities of endotoxin on the procoagulant activity of rabbit leukocytes. Incubation mixture as for Table I, except that platelets were replaced by Tyrode's solution.

Pretreatment of platelet membranes with gangliosides resulted in a loss of their ability to influence the tissue factor activity of leukocytes in the presence of endotoxin. Similarly, membranes extracted with chloroform: methanol lost their enhancing effect (Table V).

Effect of increasing amounts of endotoxin on the procoagulant activity of rabbit leukocytes. To determine whether increasing amounts of endotoxin produced a cumulative effect, leukocytes were incubated with varying quantities of endotoxin, and the clot-promoting activity was evaluated. Significant procoagulant activity could be obtained in the presence of $5 \mathrm{ng}$ per $\mathrm{ml}$ of endotoxin. As shown in Fig. 2, larger amounts of endotoxin did not significantly increase the clotting activity of leukocytes. Quantities in the range of $50 \mu \mathrm{g}$ showed slight inhibition. When adsorbed serum was added to the incubation mixture, results were similar to those shown in Fig. 2. The absence of a cumulative effect was not attributable to individual endotoxin preparations, since five different endotoxins were evaluated together and separately with similar results.

\section{DISCUSSION}

The initial data obtained in these studies confirm previous observations on the procoagulant activity generated by rabbit leukocytes (9). In addition, it was demonstrated that when rabbit leukocytes and rabbit platelets were incubated together, the clot-promoting activity generated by the leukocytes was higher than that observed after incubation of leukocytes alone. Furthermore, the activity was even more pronounced if the platelets were disrupted before incubation. It was also shown that the activity generated in the incubation system was produced by the leukocytes and not the platelets. Indeed, in control studies where platelets were incubated alone or in the presence of endotoxin or disrupted leukocytes little or no tissue factor activity was generated. It has therefore been concluded that platelets enhance the activity of leukocytes. 
The active principle producing this enhancement is thermolabile and disappears in approximately $48 \mathrm{~h}$.

Of additional interest were the results of experiments in which endotoxin was added to the leukocyte-platelet incubation system. Under these conditions the presence of platelets markedly increased the quantity and rate of generation of procoagulant activity by the leukocytes. The platelet "enhancing activity" was thermostable in nature and could be detected in platelets or subcellular platelet particles even after 2 wk of storage at $4^{\circ} \mathrm{C}$. It thus appears that there may be two separate and distinct "enhancing factors" associated with platelets: one that is thermolabile, acting in the presence of leukocytes alone, and the other thermostable, producing its effect on leukocytes in the presence of endotoxin. When rabbit leukocytes were tested in the presence of human platelets, a comparable "enhancing effect" was observed, suggesting that the platelet effect was not species specific.

Experiments involving human leukocytes in the presence of human platelets were of interest. No enhancement of the procoagulant activity of leukocytes occurred unless human serum (adsorbed with tricalcium phosphate) was added. This suggested that in the case of human platelets and human leukocytes a serum factor was required for elucidation of the platelet enhancing effect. The possibility that the serum had contributed small amounts of coagulation factors VII or X to the assay system was eliminated (8) and further ruled out in the following manner: the adsorbed sera were tested in a two-stage assay system (in place of the usual barium sulfate eluate) for the presence of VII or X activity, and none could be detected. It was also of interest that disruption of human platelets before incubation did not augment their enhancing effect on human leukocytes. This was in contrast to the rabbit system and remains unexplained. It was also observed that higher quantities of human leukocytes were necessary to elicit a procoagulant effect comparable to that obtained with rabbit leukocytes. This phenomenon is consistent with previous studies (9).

When the enhancing effect of human platelet subcellular fractions was tested on rabbit leukocytes in the presence of endotoxin, the platelet granules, membranes, and soluble fraction appeared to have a comparable effect as evaluated in the one-stage test. In marked contrast, however, the tissue factor activity (as assayed by the two-stage system) was enhanced more than sevenfold by the platelet granules and membranes, whereas the soluble fraction produced very little effect. This suggested that the platelet "enhancing activity" was particulate in nature. It should be pointed out that the two-stage assay is more specific for tissue factor activity.
When platelet membranes were exposed to trypsin before incubation, the enhancing effect on the coagulant activity of the leukocytes was increased. This phenomenon was demonstrable even in the absence of endotoxin, which suggested that tryptic digestion of the platelet membrane proteins increased the availability of the clotpromoting "site" for leukocyte interaction. Since trypsintreated platelet membranes had no activity in the twostage assay, their effect on leukocytes could not have been due to traces of trypsin remaining on the washed membranes. After treatment of the platelet membranes with phospholipase $\mathrm{C}$, their ability to influence the generation of procoagulant activity by the leukocytes was completely abolished. Although the hydrolytic products of this enzyme treatment were not measured, it is postulated that phospholipase $\mathrm{C}$ produced an alteration in the basic lipoprotein configuration of the platelet membrane which no longer permitted it to interact with the leukocyte. The possibility that residual traces of phospholipase $C$ acted on the leukocyte surface itself could not be completely ruled out. Preincubation of the platelet membranes with neuraminidase had no effect on the platelet-leukocyte interaction. This indicated that sialic acid residues from susceptible sites were not essential for the reaction. It is not known whether the released sialic acid was cleaved from platelet membrane glycoproteins or gangliosides (24).

Platelet membranes lost their leukocyte-enhancing effect after incubation with gangliosides. These results are reminiscent of recently reported investigations of the affinity of gangliosides for cell membranes (25). Cuatrecasas has shown that incubation of intestinal epithelial cells with gangliosides prevents these cells from interacting with cholera toxin (25). The results may not be entirely explicable on the basis of a physical ganglioside-membrane interaction since gangliosides were only moderately effective in preventing the attachment of radioactive endotoxin to platelet membranes. ${ }^{\text {.5 }}$

After extraction of the platelet membranes with chloroform: methanol the delipidated residue was completely devoid of the enhancing effect on leukocytes. This observation indicated that platelet lipids were essential for the enhancing activity. When the extracted platelet membrane lipids were added back to the incubation system, the enhancing effect was partially restored.

Since platelets are known to possess phagocytic properties $(26,27)$, it could be postulated that the enhancing effect was attributable to platelet phagocytosis of endotoxin. This might result in the accumulation of increasing amounts of endotoxin on the platelet surface and in the platelet hyaloplasm. However, we have shown that the effect of endotoxin on leukocytes is not cumulative

\footnotetext{
${ }^{13} \mathrm{~J}$. Niemetz. Unpublished observations.
} 
(Fig. 2) and appears to be an "all-or-none" phenomenon, making the above possibility unlikely.

There is considerable experimental evidence to indicate that the enhancing activity observed is platelet specific. For example, platelets or subcellular platelet particles which had been delipidated had no effect, nor did sonically disrupted leukocytes or erythrocytes. Furthermore, zymosan particles could not be substituted for platelets.

Finally, control experiments were carried out on the components of incubation mixtures to test for factors VII and $\mathrm{X}$ and thrombin activity which could have influenced the results. These activities were undetectable.

\section{ACKNOWLEDGMENTS}

We wish to thank Barbara Troy, Maria E. Cheriego, Lenore Safier, and Harris Ullman for excellent assistance.

This study was supported by grants from the Veterans Administration (project 6069-01), the National Institutes of Health (HL-13155-05 and HL-09070-10), the New York Heart Association, and the S. M. Louis Memorial Fund for Research in Thrombosis and Atherosclerosis.

\section{REFERENCES}

1. Martin, H., and L. Roka. 1951. Beinflussung der Blutgerinnung durch leukocyten. Klin. Wochenschr. 29: 510-512.

2. Lisiewicz, J. 1969. Studies on the influence of normal and leukemic leukocytes on blood coagulation. Ann. Med. Sect. Pol. Acad. Sci. 13: 233-278.

3. Eiseman, G., and M. Stefanini. 1954. Thromboplastic activity of leukemic white cells. Proc. Soc. Exp. Biol. Med. 86: 763-765.

4. Rapaport. S. I., and P. F. Hjort. 1967. The blood clotting properties of rabbit peritoneal leukocytes in vitro. Thromb. Diath. Haemorrh. 17: 222-236.

5. Gralnick, H. R., and E. Abrell. 1973. Studies of the procoagulant and fibrinolytic activity of promyelocytes in acute promyelocytic leukemia. Br. J. Haematol. 24 : 89-99.

6. Niemetz, J. 1972. Coagulant activity of leukocytes. Tissue factor activity. J. Clin. Invest. 51: 307-313.

7. Lerner, R. G., R. Goldstein, and G. Cummings. 1971. Stimulation of human leukocyte thromboplastic activity by endotoxin. Proc. Soc. Exp. Biol. Med. 138: 145-148.

8. Niemetz, J. 1972. The role of protein synthesis on the generation of tissue factor activity by leukocytes. Proc. Soc. Exp. Biol. Med. 139: 1276-1279.

9. Garg, S. K., and J. Niemetz. 1973. Tissue factor activity of normal and leukemic cells. Blood J. Hematol. 42: 729-735.

10. Niemetz, J., and K. Fani. 1973. Thrombogenic activity of leukocytes. Blood J. Hematol. 42: 47-59.

11. Saba, H. I., J. C. Herion, R. I. Walker, and H. R. Roberts. 1973. The procoagulant activity of granulocytes. Proc. Soc. Exp. Biol. Med. 142: 614-620.
12. Kociba, G. J., W. F. Loeb, and R. F. Wall. 1972 Development of procoagulant (tissue thromboplastin) activity in cultured leukocytes. J. Lab. Clin. Med. 79: 778-787.

13. Rickles, F. R., J. A. Hardin, F. A. Pitlick, L. W. Hoyer, and M. E. Conrad. 1972. Tissue factor activity in lymphocyte cultures from normal individuals and patients with hemophilia A. J. Clin. Invest. 52: 14271434.

14. Biggs, R., K. W. E. Denson, D. Riesenberg, and C. McIntyre. 1968. The coagulant activity of platelets. $\mathrm{Br}$. J. Haematol. 15 : 283-296.

15. McKay, D. G., and S. S. Shapiro. 1958. Alterations in the blood coagulation system induced by bacterial endotoxin. I. In vivo (generalized Shwartzman reaction). J. Exp. Med. $107:$ 353-367.

16. Graeff, H., and F. K. Beller. 1968. Hematological studies during endotoxin infusion in rabbits. Thromb. Diath Haemorrh. 20: 420-429.

17. Toth, S., T. Szilagyi, M. Went, and G. Levai. 1972. Preparation of local Shwartzman reaction by means of platelet rich plasma. Acta Physiol. Acad. Sci. Hung. 42: 163-168.

18. Ardlie, N. G., M. A. Packham, and J. F. Mustard. 1970. Adenosine diphosphate-induced platelet aggregation in suspensions of washed rabbit platelets. $\mathrm{Br}$. J. Haematol. 19: 7-17.

19. Ardlie, N. G., D. W. Perry, M. A. Packham, and J. F. Mustard. 1971. Influence of apyrase on stability of suspensions of washed rabbit platelets. Proc. Soc. Exp. Biol. Med. 136: 1021-1023.

20. Marcus, A. J., D. Zucker-Franklin, L. B. Safier, and H. L. Ullman. 1966. Studies on human platelet granules and membranes. J. Clin. Invest. 45: 14-28.

21. Marcus, A. J., H. L. Ullman, and L. B. Safier. 1972. Studies on human platelet gangliosides. J. Clin. Invest. $51: 2602-2612$.

22. Lowry, O. M., N. J. Rosebrough, A. L. Farr, and R. J. Randall. 1951. Protein measurement with the Folin phenol reagent. J. Biol. Chem. 193: 265-275

23. Nemerson, Y. 1966. The reaction between bovine brain tissue factor and factors VII and X. Biochemistry. 5: 601-608.

24. Marcus, A. J., L. B. Safier, and H. L. Ullman. 1973. Interaction between neuraminidase and isolated platelet gangliosides. In Erythrocytes, Thrombocytes, Leukocytes: Recent Advances in Membrane and Metabolic Research. E. Gerlack, K. Moser, E. Deutsch, and W. Wilmanns, editors. Georg Thieme Verlag KG., Stuttgart. 233-235.

25. Cuatrecasas, P. 1973. Gangliosides and membrane receptors for cholera toxin. Biochemistry. 12: 3558-3566.

26. Glynn, M. F., H. Z. Movat, E. A. Murphy, and J. F. Mustard. 1965. Study of platelet adhesiveness and aggregation with latex particles. J. Lab. Clin. Med. 65: 179-201.

27. David-Ferreira, J. R. 1960. Demonstration du pouvoir phagocytaire des plaquettes sanguines chez le lapin. Proc. Eur. Reg. Conf. Electron Microsc. 2: 917-921. 